\title{
A Cameroonian Traditional Cake (Komba) Prepared Using Yellow Maize Reduce Vitamin A Deficiency in Lactating Mothers
}

\author{
Ngaha Damndja Wilfred', Ejoh Aba Richard ${ }^{1,2}$, Fombang Nig Edith1, Gouado Inocent ${ }^{3}$ \\ ${ }^{1}$ Department of Food Sciences and Nutrition, National School of Agro-Industrial Sciences, University of Ngaoundere, \\ Ngaoundere, Cameroon \\ ${ }^{2}$ Department of Food and Bioresource Technology, College of Technology, The University of Bamenda, Bambili, Cameroon \\ ${ }^{3}$ Department of Biochemistry, Faculty of Sciences, University of Douala, Douala, Cameroon \\ Email: *ejohrab@yahoo.com
}

How to cite this paper: Wilfred, N.D., Richard, E.A., Edith, F.N. and Inocent, G. (2018) A Cameroonian Traditional Cake (Komba) Prepared Using Yellow Maize Reduce Vitamin A Deficiency in Lactating Mothers. Food and Nutrition Sciences, 9, 247-258.

https://doi.org/10.4236/fns.2018.93019

Received: February 11, 2018

Accepted: March 26, 2018

Published: March 29, 2018

Copyright $(0) 2018$ by authors and Scientific Research Publishing Inc. This work is licensed under the Creative Commons Attribution International License (CC BY 4.0).

http://creativecommons.org/licenses/by/4.0/

\section{c) (i) Open Access}

\begin{abstract}
Vitamin A deficiency (VAD) is a widespread public health problem in developing nations affecting greatly pregnant and lactating women. To alleviate the deficiency, many strategies were set up by the Cameroonian authorities. However, the level of VAD is still very high, thus the option of supplementation of foods remains a very important option. The aim of this study was to evaluate the impact of a food supplementation with komba, a Cameroonian traditional yellow maize cake, on vitamin A status of lactating mothers in Ngaoundere town. To achieve this, 40 lactating mothers were recruited in four health facilities of the Ngaoundere town. They were dewormed and subdivided in two groups of 20 subjects each and fed for two months. The test group received $200 \mathrm{~g}$ of yellow maize cake while the control group received $200 \mathrm{~g}$ of white maize. 24-hour dietary recall was used to assess their food intake during the study period. Blood sample were collected at the beginning and the end of the study and the serum retinol determined. Results show that before the supplementation, $45 \%$ of the women had inadequate level of serum retinol in each group. At the end of the 2 months of supplementation, $30 \%$ of the control group remained inadequate, while the totality of all the women in the test group had adequate serum retinol levels $(\geq 1.05 \mu \mathrm{mol} / \mathrm{l})$. That means an improvement of the vitamin A status in the test group. Results also show a significant $(\mathrm{p}<0.05)$ increase of $36.3 \%$ of serum retinol in the test group against $3.8 \%$ in the control group. The women of the test group had more chances to see their serum retinol increasing compared to the control group. Consumption of yellow maize cake therefore improves the vitamin A status of lactating mothers. The population can therefore change their habits to consume yellow maize instead of the white maize variety popularly consumed.
\end{abstract}




\section{Keywords}

Food Supplementation, Yellow Maize Cake, Lactating Mothers, Vitamin A Status

\section{Introduction}

Vitamin A Deficiency (VAD) remains a problem of public health in many developing countries [1], and the primary cause is the insufficient dietary intake of this vitamin. In Cameroon, the Northern Regions (Adamawa, North and Far North) are the most concerned with $62.5 \%$ children affected [2]. In Ngaoundere, a town located in Adamawa Region, VAD risk is severe and acute for $20 \%$ and $35 \%$ pregnant women respectively [3], and acute for 34\% lactating mothers [4]. Vitamin A (VA) intake of this population is influenced primarily by their food habits [5] [6]. In spite of the efforts made by the Cameroonian authorities, particularly Vitamin A supplementation with capsules, deworming children of 6 to 59 months twice per year [7], and the fortification in VA of some commonly consumed foods (vegetable oils, flour, dairy products) [8], the rate of VAD remains high. It thus appears important to think of other alternatives to complement these efforts that will change the behaviors of the target population toward other Vitamin A rich foods.

Several studies showed the positive effect of food supplementation on VA status of the populations [9] [10]. Yellow maize has been shown to be rich in beta carotenes, a primary precursor of vitamin A [11]. This food crop has been found to have a high potential to maintain the hepatic reserves of retinol in animals [12] [13]. Supplementation with the yellow variety of maize, a staple in this region of Cameroon can go a long way to alleviate VAD. Maize production in this region (Adamawa) is about 72,668 tons [14]. It is consumed in various forms in Cameroon: boiled whole grains, porridge, couscous and cake (komba). Komba, a traditional maize cake widely consumed in the country, requires for its preparation the addition of ingredients such as vegetable oil and roasted groundnut paste that make it an interesting food matrix for optimal bioconversion and absorption of VA, a fat soluble vitamin. The aim of this study was thus to evaluate the impact of a food supplementation with a traditional yellow maize cake on VA status of the lactating mothers in the town of Ngaoundere, Cameroon.

\section{Material and Methods}

\subsection{Area of the Study}

The study was conducted in the town of Ngaoundere, in the Adamawa Region of Cameroon, located in the Northern part of the country. The characteristics of the town have previously been described [3] [4].

\subsection{Preparation of Cakes}

White and yellow maize flours were produced as describe in Figure 1, in absence 
of sunlight to avoid the oxidation of carotenoids. Roasted groundnut paste was obtained from groundnuts whole grain as described in Figure 2. Yellow maize and white maize cakes were then prepared by mixing maize flours, ingredients and groundnut paste as summarized in Figure 3.

\subsection{Recruitment and Deworming of the Subjects}

Ethical approval for this study was obtained from the ethical committee of Ngaoundere Regional Hospital. Lactating mothers having given their consent

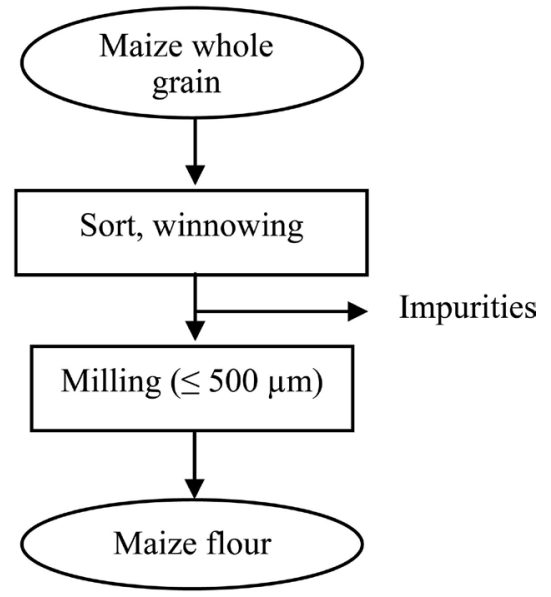

Figure 1. Diagram of production of white maize and yellow maize flours.

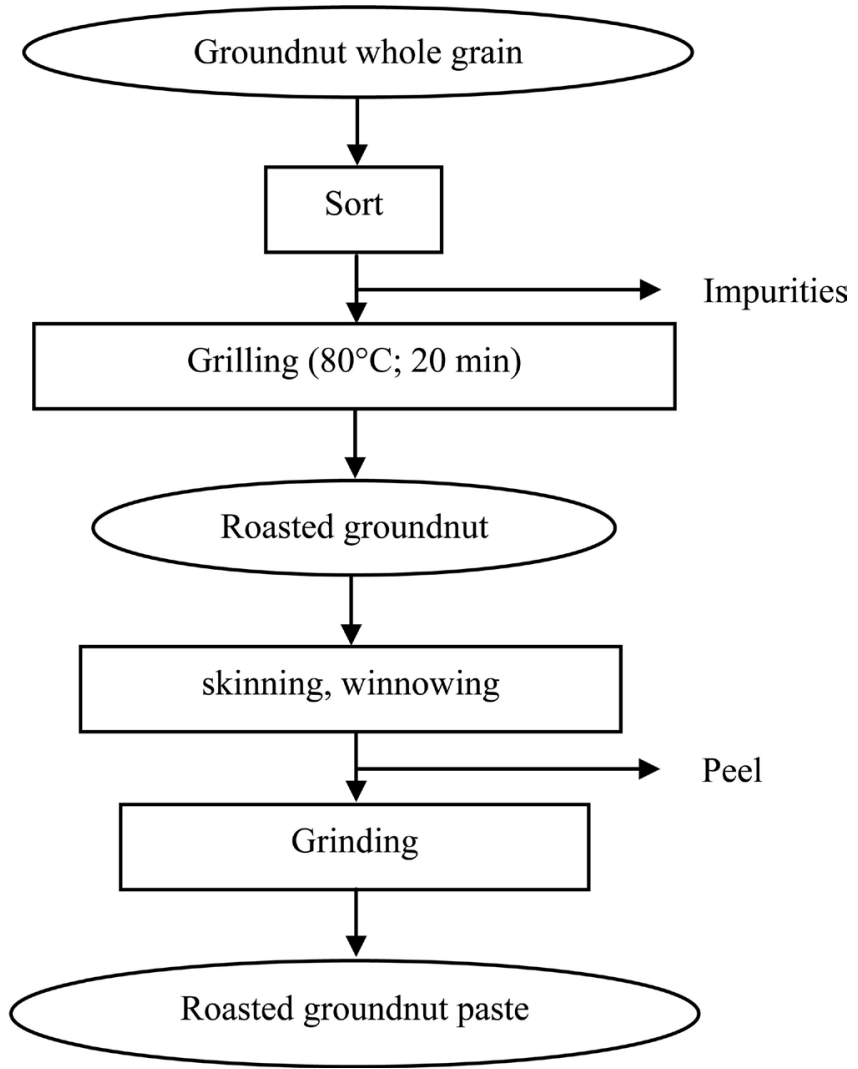

Figure 2. Diagram of production of roasted groundnut paste. 
Water $(500 \mathrm{ml})$

Vegetable oil $(100 \mathrm{ml})$

Kitchen salt $(50 \mathrm{~g})$

Seasonings (3 cubes)

Roasted groundnut paste (250g)

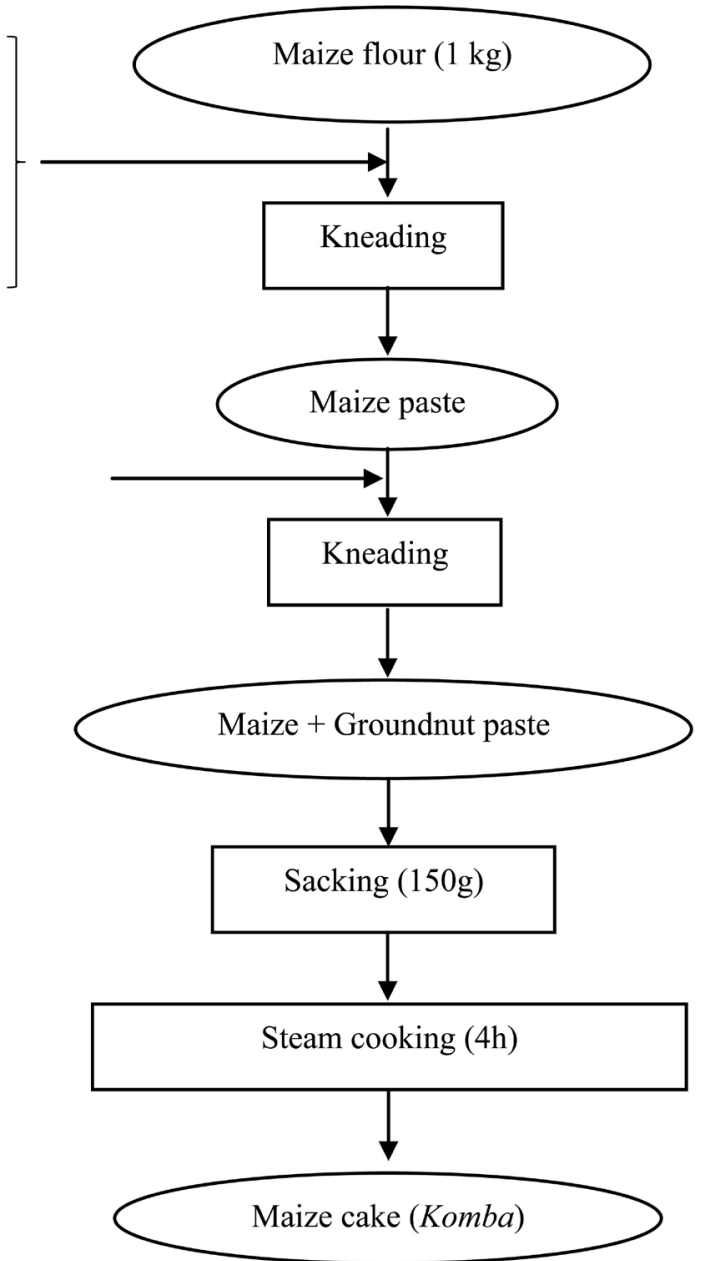

Figure 3. Diagram of preparation of Komba.

were recruited according to inclusion criteria defined, in four health facilities representing the three districts of Ngaoundere town. Mothers were from 15 to 40 years old, practicing exclusive breast-feeding, being under no medication nor particular diet, and having babies aged 3 months or less. All those who did not meet these criteria were excluded from the study. 40 lactating mothers were retained and dewormed during the week before the beginning of the trial by receiving $1200 \mathrm{mg}$ of Mebendazole to eliminate possible intestinal parasites (2 tablets $/ 2$ times daily $/ 3$ days) and a single dose of three tablets of Fansidar (composition for a tablet:Sulfadoxine BP 500mg, Pyrimethamine BP $25 \mathrm{mg}$ ) to prevent malaria.

\subsection{Food Supplementation of the Subject's Diet}

The supplementation consisted daily administration of $200 \mathrm{~g}$ of yellow maize cake during 60 days as test diet to a group of 20 women representing the experimental group. Under the same conditions, a group of 20 other women representing the control group received $200 \mathrm{~g}$ of white maize cake. This was done without modification of their usual diets. During the supplementation, the normal diets 
of the subjects were assessed using 24-hour dietary recall. An estimation of VA intake from normal diet was done using food composition table [3] [4] [5] [6]. The study started on the $25^{\text {th }}$ of August 2010 when the women were recruited for the study till the $20^{\text {th }}$ of November 2014 when the intervention was completed. The experimental process is summarized on Figure 4.

\subsection{Collection, Transport and Treatment of Blood Samples}

Blood samples were collected on dry tubes by venous puncture. The tubes were wrapped with foil to avoid oxidation of retinol by sunlight. Two drops of 2 , 6-diterbutyl-4 methyl phenol, an antioxidant, were added to each blood sample. The samples were then transported in an icebox to the laboratory and centrifuged at $3000 \mathrm{G}$ for 10 minutes. The serum was then decanted, and frozen in eppendorf tubes at $-20^{\circ} \mathrm{C}$ for serum retinol determination.

\subsection{Nutritional Composition and VA Activity}

Dry matter [15], oil [16], total proteins [17] [18], total sugars [19] and crude fibers [20] contents of white and yellow maize flours, roasted groundnut paste, white and yellow maize cake were determined, since these macronutrients have

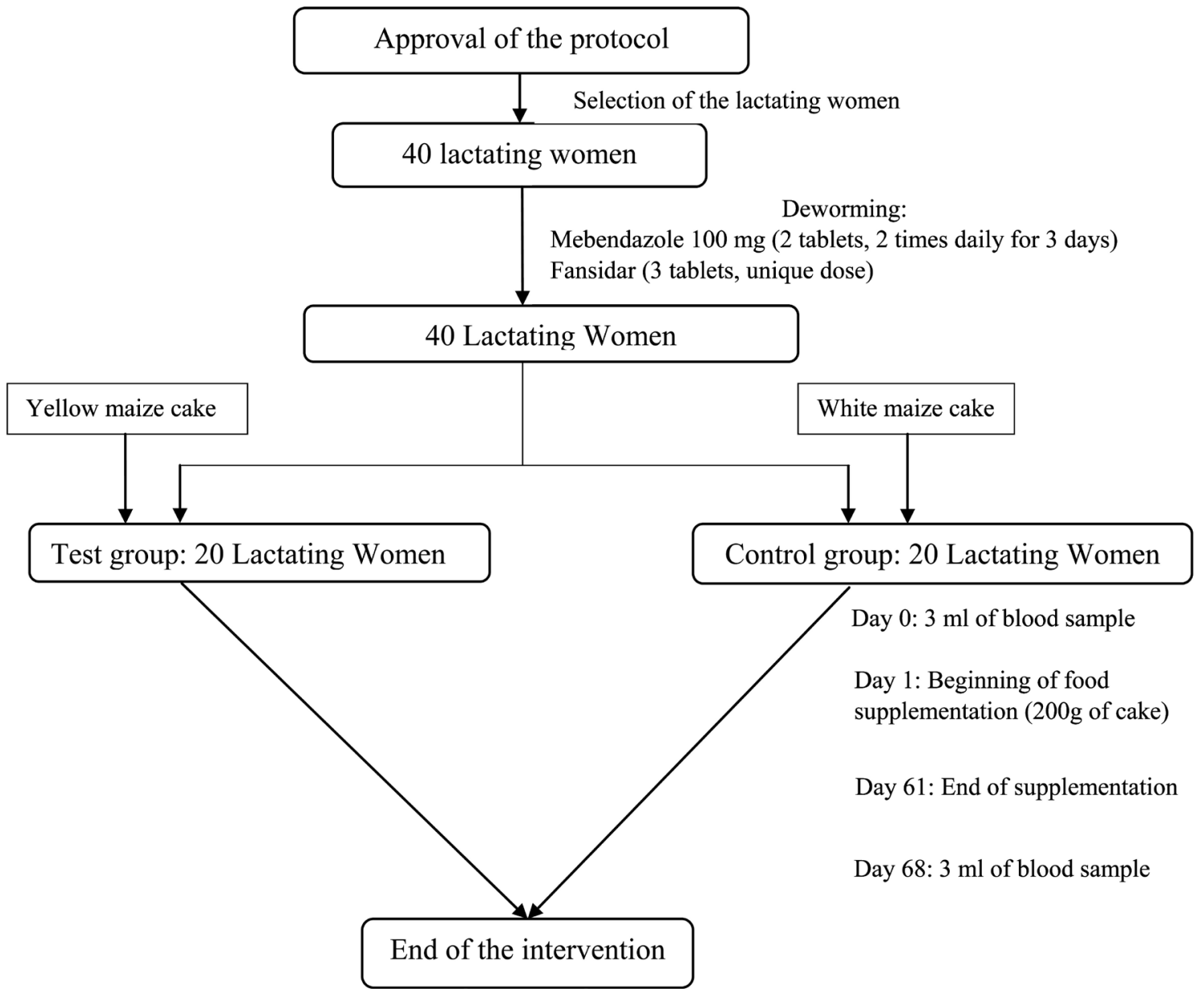

Figure 4. Experimental diagram of the intervention. 
an established influence on VA absorption and metabolism. Carotenoids content [21] was also determined and VA activity computed based on the assumption that $12 \mu \mathrm{g}$ of dietary carotenoid yields $1 \mu \mathrm{g}$ of VA [22].

\subsection{Quantification of Serum Retinol and Vitamin A Status of the Mothers}

Serum retinol was measured by a UV spectrophotometry method [23] and VA status of the women determined according to the values thresholds defined by WHO [24] and presented in Table 1.

\subsection{Statistical Analysis}

The data obtained in this study was subjected to analysis of variance (ANOVA) and means separated using the least significant difference test with the statistical software Stat graphics centurion at the $5 \%$ level of significance. Where appropriate, percentages (\%) were calculated. Results are presented as means and standard deviation of three determinations.

\section{Results}

\subsection{Nutritional Composition and VA Activity}

Nutritional composition and VA activity of cakes are presented in Table 2 and Table 3. From Table 2 there is no significant difference between komba made from yellow and white maize. Both are good sources of sugars, proteins, oils, and energy. Table 3, shows that komba made from yellow maize is a good source of carotenoids with an average of $2.88 \mathrm{mg}$, corresponding to a VA activity of 250

Table 1. Classification of vitamin A status according to serum retinol level [24].

\begin{tabular}{cc}
\hline Serum retinol level $(\mu \mathrm{mol} / \mathrm{l})$ & Vitamin A status \\
\hline$<0.35$ & Severe deficiency \\
$0.35-0.69$ & Poor \\
$0.7-1.05$ & Inadequate \\
$>1.05$ & Appropriate \\
\hline
\end{tabular}

Table 2. Macronutrients composition of the ingredients and maize cakes (dry basis)*.

\begin{tabular}{|c|c|c|c|c|c|c|}
\hline Samples & $\begin{array}{c}\text { Water } \\
\text { content (\%) }\end{array}$ & Oils (g) & Proteins (g) & Sugars (g) & Fibers (g) & $\begin{array}{c}\text { Energy } \\
\text { (kcal) }\end{array}$ \\
\hline Yellow maize flour & $11.31 \pm 0.33^{\mathrm{b}}$ & $4.85 \pm 0.23^{\mathrm{a}}$ & $10.31 \pm 0.71^{\mathrm{a}}$ & $72.63 \pm 1.15^{\mathrm{c}}$ & $9.83 \pm 0.18^{\mathrm{e}}$ & 375.41 \\
\hline White maize flour & $10.64 \pm 0.38^{\mathrm{b}}$ & $4.60 \pm 0.26^{\mathrm{a}}$ & $10.04 \pm 0.47^{\mathrm{a}}$ & $72.79 \pm 0.97^{\mathrm{c}}$ & $9.12 \pm 0.20^{\mathrm{d}}$ & 372.72 \\
\hline $\begin{array}{c}\text { Roasted groundnut } \\
\text { paste }\end{array}$ & $8.31 \pm 0.17^{\mathrm{a}}$ & $45.39 \pm 0.78^{c}$ & $26.12 \pm 0.70^{\mathrm{d}}$ & $19.04 \pm 0.93^{\mathrm{a}}$ & $3.84 \pm 0.47^{\mathrm{a}}$ & 589.15 \\
\hline Yellow maize cake & $51.72 \pm 1.04^{\mathrm{c}}$ & $24.30 \pm 0.54^{\mathrm{b}}$ & $15.70 \pm 0.89^{c}$ & $48.36 \pm 0.81^{\mathrm{b}}$ & $7.33 \pm 0.25^{c}$ & 474.94 \\
\hline White maize cake & $51.09 \pm 0.86^{\mathrm{c}}$ & $23.84 \pm 0.61^{b}$ & $14.25 \pm 1.04^{\mathrm{b}}$ & $48.68 \pm 1.45^{\mathrm{b}}$ & $6.68 \pm 0.47^{\mathrm{b}}$ & 466.28 \\
\hline
\end{tabular}


Table 3. Carotenoid content and vitamin A activity of the ingredients and maize cakes (dry weight basis)*.

\begin{tabular}{cccc}
\hline Samples & Water content $(\%)$ & Carotenoids $(\mathrm{mg})$ & VA Activity $(\mu \mathrm{g})$ \\
\hline Yellow maize flour & $11.31 \pm 0.33^{\mathrm{b}}$ & $3.12 \pm 0.38^{\mathrm{b}}$ & 260 \\
White maize flour & $10.64 \pm 0.38^{\mathrm{b}}$ & $0.38 \pm 0.07^{\mathrm{a}}$ & 30 \\
Roasted groundnut paste & $8.31 \pm 0.17^{\mathrm{a}}$ & $0.02 \pm 0.00^{\mathrm{a}}$ & $/$ \\
Yellow maize cake & $51.72 \pm 1.04^{\mathrm{c}}$ & $2.88 \pm 0.43^{\mathrm{b}}$ & 250 \\
White maize cake & $51.09 \pm 0.86^{\mathrm{c}}$ & $0.24 \pm 0.02^{\mathrm{a}}$ & 20 \\
\hline
\end{tabular}

*Values with different superscript letters in the same column indicates a significant difference $(\mathrm{p}<0.05)$.

$\mu \mathrm{g}$, as against $20 \mu \mathrm{g}$ of VA activity in komba made from white maize, which confirms the keen interest on yellow maize as a source of VA.

\subsection{Average Daily Intake of Vitamin A}

Table 4 shows the VA intake with and without supplementation. The normal diet of the women did not cover their daily VA needs, with $82.2 \%$ and $77.1 \%$ of coverage for the control and test group respectively. However, with the consumption of komba, this level of coverage rose to $110.9 \%$ in the test group, expressing an improvement of $33.8 \%$, while the level remained insufficient in control group (84.5\%).

\subsection{Serum Retinol Level of the Women}

Serum retinol of the subjects before and after the supplementation is presented in Table 5. There is an increase of $36.3 \%$ of the average serum retinol level from 1.02 to $1.39 \mu \mathrm{mol} / \mathrm{l}$ in the test group, as against $3.8 \%$ increase in the control group. Thus, the mothers having consumed komba made using the yellow maize has more chance to have their serum retinol increase, compared to the women having consumed white maize. In addition, the post supplementation mean retinol serum in the test group is largely higher than the threshold of $1.05 \mu \mathrm{mol} / \mathrm{l}$ considered as appropriate by WHO [24].

\subsection{Vitamin A Status of the Mothers}

Table 6 presents the general situation of the studied women before and after the intervention. Before the intervention, for both the test and the control groups, $45 \%$ of the women had an inadequate VA status. The consumption of yellow komba made it possible to improve this status in the test group as supplementation enable all the women in the test group to have an adequate VA status, against $30 \%$ who were still having inadequate levels in the control group thus low VA status.

\section{Discussion}

The maize cake are being consumed directly after cooking and therefore in its wet form. The carotenoids content on wet basis was $1.39 \pm 0.21 \mathrm{mg}$ and corresponds 
Table 4. Average consumption of VA of the lactating women during the study.

\begin{tabular}{ccc}
\hline & \multicolumn{2}{c}{ Daily vitamin A consumption $(\mu \mathrm{g})$} \\
\hline & $\begin{array}{c}\text { Without cake } \\
\text { Consumption (level of coverage) }\end{array}$ & $\begin{array}{c}\text { With cake } \\
\text { Consumption (level of coverage) }\end{array}$ \\
\hline Control group & $698.7 \pm 72.9^{\mathrm{a}}(82.2 \%)$ & $718.7 \pm 72.9^{\mathrm{a}}(84.5 \%)$ \\
Test group & $655.2 \pm 89.4^{\mathrm{a}}(77.1 \%)$ & $887.2 \pm 89.4^{\mathrm{b}}(110.9 \%)$ \\
\hline
\end{tabular}

Values with different superscript letters are significantly different $(\mathrm{p}<0.05)$.

Table 5. Effect of supplementation on serum retinol level of the lactating mothers.

\begin{tabular}{ccc}
\hline & \multicolumn{2}{c}{ Serum retinol level $(\mu \mathrm{mol} / \mathrm{l})$} \\
\hline & Test group $(\mathbf{n}=20)$ & Control group $(\mathbf{n}=20)$ \\
\hline Before supplementation & $1.02 \pm 0.11^{\mathrm{a}}$ & $1.06 \pm 0.11^{\mathrm{a}}$ \\
After supplementation & $1.39 \pm 0.09^{\mathrm{b}}$ & $1.10 \pm 0.05^{\mathrm{a}}$ \\
\hline
\end{tabular}

Values with different superscript letters are significantly different $(\mathrm{p}<0.05)$.

Table 6. Effect of supplementation on the vitamin A status of the studied population.

\begin{tabular}{cccc}
\hline \multirow{2}{*}{ Period of the study } & Retinol range & \multicolumn{2}{c}{ Percentage of women (\%) } \\
\cline { 3 - 4 } & & Control & Test \\
\hline \multirow{2}{*}{ Before supplementation } & Appropriate & 55 & 55 \\
& Inadequate & 45 & 45 \\
& Appropriate & 70 & 100 \\
After supplementation & Inadequate & 30 & 0
\end{tabular}

Total number $\mathrm{n}=40$ women; Test group: 20 women; Control group: 20 women.

to a VA activity of $116 \mu \mathrm{g}$, that is to say it covers approximately $30 \%$ of the daily needs in VA after consumption of $200 \mathrm{~g}$ of the cake made with yellow maize. These results are in line with results obtained in Zimbagwe where $412 \mu \mathrm{g}$ of vitamin A activity was found when $330 \mathrm{~g}$ of a meal made up of maize pulp containing $300 \mathrm{~g}$ of yellow maize, $20 \mathrm{~g}$ of butter and a capsule of $0.5 \mathrm{~g}$ of maize oil [11].

The oil content of komba made using yellow maize is suitable for VA activity as insufficient oil consumption can significantly reduce its bioconversion and absorption [25]. Moreover, carotenoids contained in raw fruit and vegetables devoid of oil are only slightly absorbed (less than $3 \%$ ), while pure $\beta$-carotene dissolves in an oily suspension is absorbed in a more efficient way (higher than 50\%) [26]. It is therefore important for consumption of provitamin A rich products together with oil for maximum absorption. The rich proteins content in $k o m b a$ is an added advantage taking into consideration that transportation of retinol from liver to tissue is done by combination with Retinol Binding Protein produced in liver [27]. Therefore, the ingestion of small quantities of proteins can have a negative influence on transport, and thus the availability and the use of the retinol in the organism. Caloric deficit of diets is one of the secondary causes of VAD. The rather high levels of sugar in combination with the oil in 
komba that provides calories is beneficial for maximum VA activity. Fibers in excess in the diet reduce the bioavailability of carotenoids by imprisoning them or by interacting with biliary acids, with as consequence the increase in the fecal excretion of lipids and fat soluble substances [28]. Low fibers content in komba is therefore beneficial for the absorption of carotenoids contained in the cake.

Results have shown that komba prepared with yellow maize flour is an interesting source of VA, and its macronutrients composition makes it an ideal food matrix for optimal bioconversion and absorption of VA. This experiment was carried out on lactating mothers to see if the VA contained in komba is really absorbed. As expected, consumption of komba improved VA status of mothers (100\% of improvement) by significantly increasing their serum retinol $(36.3 \%$ of increase), and these results are linked to factors like deworming, nature of food matrix, type of intervention, time and level of supplementation. A study conducted in Douala (Cameroon) showed that consumption of papaya and mango does not have significant postprandial effects on serum retinol [29], though the fruits are important source of provitamin A carotenoids. This could be explained by the absence of deworming and poor oil content of the fruits used in the study. Several studies have showed the importance of deworming [30] [31] and oil supply [25] [26] in VA supplementation.

In Niger, a supplementation during 6 weeks, increased by $31.34 \%$ the serum retinol of the subjects. This was justified by the fact that either the level of supplementation was too low to cover the needs in vitamin, or duration was too short to bring back the status of the individuals severely deprived to the normal level. The level and time of supplementation need to be well estimated before any food supplementation study can show significant outcome. In Burkina Faso, a nutritional intervention consisting in promoting the consumption of the palm oil by subsidies led to a rate of improvement in VA status of $55 \%$ of the target populations [10]. The rest of the $45 \%$ of the population were either those that did not include the palm oil in their diet or those who still found the price of palm oil still expensive in spite of the subsidy. It is thus important to take into account the food behaviors and the average income of the populations in the implementation of the food interventions.

\section{Conclusion}

The regular consumption of komba prepared using yellow maize improves vitamin A status of the lactating women in Ngaoundere (Cameroon). The populations should be recommended to consume yellow maize as oppose to the white variety in the hearths of VAD. The vulgarization of production of yellow maize to make it more available all over the country will be important to contribute to the alleviation VAD in Cameroon.

\section{Acknowledgements}

The authors will like to thank the lactating women who participated in this 
study, giving free their time and their blood for the preferment of science.

\section{References}

[1] Williams, I.O., Parker, R.S. and Swanson, J. (2009) Vitamin A Content of Southeastern Nigerian Vegetable Dishes, Their Consumption Pattern and Contribution to Vitamin A Requirement of Pregnant Women in Calabar Urban, Nigeria. Pakistan Journal of Nutrition, 8, 1000-1004. https://doi.org/10.3923/pin.2009.1000.1004

[2] HKI (Helen Keller International) (2015) Cameroon and Africa: Vitamin A Supplementation and Food Fortification Reducing Malnutrition and Preventing Blindness. HKI, New York.

[3] Ngaha, D.W., Fombang, E.N. and Ejoh, R.A. (2014) Dietary Intake of Vitamin A and Macronutrients among Pregnant Women in Ngaoundere Town, Adamawa Region, Cameroon. Food and Nutrition Sciences, 5, 2071-2080. https://doi.org/10.4236/fns.2014.521219

[4] Ngaha, D.W., Fombang E.N. and Ejoh R.A. (2016) Evaluation of Vitamin A Deficiency Risks among Lactating Mothers in Ngaoundere, Adamawa Region of Cameroon. International Journal of Food and Nutritional Science, 5, 86-95.

[5] Fombang, E.N., Ngaha, D.W. and Ejoh, R.A. (2016) Variability in Vitamin A Intake of Pregnant Women in Ngaoundere-Cameroon with Geographic Origin, Socio-Professional and Demographic Factors. Food and Nutrition Sciences, 7, 74-82. https://doi.org/10.4236/fns.2016.72009

[6] Ngaha, D.W., Fombang, N.E. and Ejoh, R.A. (2016) Socio-Economic and Cultural Influence on Vitamin A Intake of Lactating Mothers in Ngaoundere Cameroon. Journal of Nutritional Therapeutics, 5, 12-20. https://doi.org/10.6000/1929-5634.2016.05.01.2

[7] INS (Institut National de la Statistique) and ICF International (2012) Enquête Démographique et de Santé et à Indicateurs Multiples du Cameroun (EDS-MICS) 2011. Chapitres 3, 4, 5 et 10, INS et ICF International, Calverton. PDPP, 2013.

[8] PDPP (Projet de Descriptif de Programme de Pays) (2013) Cameroun: Projet de Descriptif de Programme de Pays 2013-2017. UNICEF, New York.

[9] Delisle, H. and Bakari, S. (2000) Effectiveness of Green Leaves as Vitamin A Sources for Schoolchildren According to Physical State of Leaves and Intestinal Parasite Load of Children. Final Research Report Submitted to Thrasher Foundation, Utah, 16.

[10] Zagré, N., Delisle, H., Tarini, A. and Delpeuch, F. (2002) Huile de palme rouge contre la carence en vitamine A: projet pilote au Burkina Faso. Cahier Santé, 12, 38-44.

[11] Muzhingi, T., Gadaga, T.H., Siwela, A.H., Grusak, M.A., Russell, R.M. and Tang, G. (2011) Un maïs jaune à forte teneur en bêta-carotène est une source appropriée de vitamine A chez des hommes en bonne santé au Zimbabwe. American Journal of Clinical Nutrition, 94, 510-519. https://doi.org/10.3945/ajcn.110.006486

[12] Howe, J.A. and Tanumihardjo, S.A. (2006) Carotenoid Biofortified Maize Maintains Adequate Vitamin A Status in Mongolian Gerbils. Journal of Nutrition, 136, 2562-2567. https://doi.org/10.1093/jn/136.10.2562

[13] Davis, C., Jing, H. and Howe, J.A. (2008). $\beta$-cryptoxanthin from Supplements or Carotenoid-Enhanced Maize Maintains Liver Vitamin A in Mongolian Gerbils (Meriones unguiculatus) Better Than or Equal to $\beta$-carotene Supplements. British Journal of Nutrition, 100, 786-793. https://doi.org/10.1017/S0007114508944123 
[14] MINADER (Ministère de l'Agriculture et du Développement Rural du Cameroun) (2012) Annuaire des statistiques du secteur agricole, campagnes 2009 et 2010. Direction des Enquêtes et des Statistiques Agricoles, AGRI-STAT N, 17.

[15] AFNOR (Association Française de Normalisation) (1982) Recueil des normes françaises des produits dérivés des fruits et légumes. Jus de fruits. 1ère éd., Paris la défense.

[16] Bourely, J. (1982) Observation sur le dosage de l'huile des graines de cotonnier. Coton et Fibres Tropicales, 27, 183-196.

[17] AFNOR (Association Française de Normalisation) (1984) Recueil de normes françaises. Produits agricoles alimentaires: Directives générales pour le dosage de l'azote avec minéralisation selon la méthode de Kjedahl. AFNOR, Paris.

[18] Devani, M.B., Shishoo, J.C., Shal, S.A. and Suhagia, B.N. (1989) Spectrophotometrical Method for Determination of Nitrogen in Kjeldahl Digest. Journal of the Association of Official Analytical Chemists, 72, 953-956.

[19] Dubois, M., Gilles, K.A., Hamilton, J.K., Roberts, P.A. and Smith, F. (1956) Colorimetric Method for Determination of Sugar and Related Substances. Analytical Chemistry, 28, 350-356. https://doi.org/10.1021/ac60111a017

[20] Wolff, J.P. (1968) Manuel d'analyse des corps gras. Azoulay éd., Paris, 519 p.

[21] AOAC (Association of Official Analytical Chemists) (1975) Methods of Analysis of the Association of Official Analytical Chemists. 10th Edition, AOAC, Washington DC.

[22] WHO (World Health Organization) (1982) Control of Vitamin A Deficiency and Xerophthalmia. World Health Organization, Geneva.

[23] Rutkowski, M., Grzegorczyk, K., Gendek, E. and Kedziora, J. (2006) Laboratory Convenient Modification of Bessey Method for Vitamin A Determination in Blood Plasma. Journal of Physiology and Pharmacology, 57, 221.

[24] WHO (World Health Organization) (2011) Serum Retinol Concentrations for Determining the Prevalence of Vitamin A Deficiency in Populations. Vitamin and Mineral Nutrition Information System. World Health Organization, (WHO/NMH/NHD/MNM/11.3), Geneva.

[25] Prince, M.R. and Frisoli, J.K. (1993) Betacarotene Accumulation in Serum and Skin. The American Journal of Clinical Nutrition, 57, 175-181. https://doi.org/10.1093/ajcn/57.2.175

[26] Stahl, W. and Sies, H. (1992) Uptake of Lycopene and Its Geometrical Isomers Is Greater from Heat-Processed than from Unprocessed Tomato Juice in Humans. Journal of Nutrition, 122, 2161-2166. https://doi.org/10.1093/jn/122.11.2161

[27] Thurnham, D.I., Northrop-Clewes, C.A., McCullough, F.S.W., Das, B.S. and Lunn, P.G. (2000) Innate Immunity, Gut Integrity, and Vitamin A in Gambian and Indian Infants. The Journal of Infectious Diseases, 182, 23-28. https://doi.org/10.1086/315912

[28] Rock, C.L. and Swendseid, M.E. (1992) Plasma Beta-Carotene Response in Humans after Meals Supplemented with Dietary Pectin. American Journal of Clinical Nutrition, 55, 96-99. https://doi.org/10.1093/ajcn/55.1.96

[29] Gouado, I., Schweigert, F.J., Ejoh, R.A., Tchouanguep, M.F. and Camp, J.V. (2007) Systemic Levels of Carotenoids from Mangoes and Papaya Consumed in Three Forms (Juice, Fresh and Dry Slice). European Journal of Clinical Nutrition, 61, 1180-1188. https://doi.org/10.1038/sj.ejcn.1602841

[30] Persson, V., Ahmed, F., Gebre-Mehdin, M. and Greiner, T. (2001) Increase in Se- 
rum $\beta$-Carotene Following Dark Green Leafy Vegetable Supplementation in Mebendazole-Treated School Children in Bangladesh. European Journal of Clinical Nutrition, 55, 1-9. https://doi.org/10.1038/sj.ejcn.1601108

[31] Takyi, E.K. (1999) Children's Consumption of Dark Green Leafy Vegetables with Added Fat Enhances Serum Retinol. The Journal of Nutrition, 129, 1549-1554. https://doi.org/10.1093/jn/129.8.1549 